\title{
EVALUATION OF MILKFAT AND MILKPROTEIN PRODUCTION IN INBRED AND OUTBRED HOLSTEIN COWS
}

\author{
J. Bezdíček, J. Šubrt, R. Filipčík, J. Říha
}

Received: May 27, 2009

\begin{abstract}
BEZDÍČEK, J., ŠUBRT, J., FILIPČÍK, R., ŘÍHA, J.: Evaluation of milkfat and milkprotein production in inbred and outbred Holstein cows. Acta univ. agric. et silvic. Mendel. Brun., 2009, LVII, No. 5, pp. 19-26

The aim of this study was to explore the depression effects of level of inbreeding on $\mathrm{kg}$ of fat and protein presented in the form of breeding values. The data included cows calved in the years 1990-2006 at farms in the Czech Republic. Inbred cows were grouped according to $F_{x}$ coefficients $\left(F_{x}=1.25 \%\right.$, $\mathrm{F}_{\mathrm{x}}=2.0-3.125 \%, \mathrm{~F}_{\mathrm{x}}=4.0-12.5 \%$ and $\mathrm{F}_{\mathrm{x}}=$ total). The breeding values for inbred cows were compared with their outbred equals (2689 equals in sum) - half-sisters, sharing the same sire, dam reaching the same breeding value $( \pm 5 \%)$ and their first calving occurring at the same farm, at the same time ( \pm 2 month). The PROC GLM of SAS ${ }^{\circ}$ with fixed effects (age at first calving, year of calving, number of lactations, first calving interval and relative breeding value of sire and dam were applied to all data). In the groups with $\mathrm{F}_{\mathrm{x}}$ coefficients $\left(\mathrm{F}_{\mathrm{x}}=1.25 \%, \mathrm{~F}_{\mathrm{x}}=2.0-3.125 \%, \mathrm{~F}_{\mathrm{x}}=4.0-12.5 \%\right.$ and $\mathrm{F}_{\mathrm{x}}=$ total $)$ we found a decrease in the breeding values of $\mathrm{kg}$ fat in inbred cows of $-1.48 ; 0.17 ;-8.26$ and $-0.51 \mathrm{~kg}$. In the case of protein content the depressed production in inbred cows was: $-0.58 ;-0.48 ;-3.21$ and $-0.94 \mathrm{~kg}$. These differences were significant $(\mathrm{p} \leq 0.01)$ in the group with the highest $\mathrm{F}_{\mathrm{x}}$ value $\left(\mathrm{F}_{\mathrm{x}}=4.0-12.5 \%\right)$. The inbred animals showed higher variability within the range of observed corrected breeding values $\left(\mathrm{Y}_{\mathrm{ijk} k \mathrm{mno}}\right)$ for $\mathrm{kg}$ of fat and protein.

The results also show that increasing the level of parents (as RBV) caused a very significant increase in production both in inbred and outbred daughters but greater increase in fat and protein was evident in the non-inbred cows.
\end{abstract}

inbreeding depression, $\mathrm{kg}$ of milkprotein, $\mathrm{kg}$ of milkfat, Holstein cows

\section{ABBREVIATIONS}

\section{BV (Breeding value), RBV (Relative breeding value for protein in $\mathrm{kg}$ )}

Levels of inbreeding in populations of dairy cattle and its influence on production is the subject of considerable research. Inbreeding has been shown to reduce reproduction in dairy cattle (Cassell et al., 2003; Cassell et al., 1998; Bezdíček et al., 2007), affect exterior (Sutherland and Lush, 1962) and other quantitative traits. Several authors have examined the effects of inbreeding on both milk yield and milk components. Allaire and Henderson, 1965 described a milk yield depression of $-12,6 \mathrm{~kg}$ for each per cent of inbreeding coefficient. This research was carried out on Holstein cattle in the USA. Gaalaas et al., (1962) examined the influence of inbreeding on milk production during the first to fourth lactation. They reported the following regression for lactations I-IV: $-47.8 \mathrm{~kg},-19.0 \mathrm{~kg},-8.2 \mathrm{~kg}$ and $-11.9 \mathrm{~kg}$ of milk. The average inbreeding depression was $-21.8 \mathrm{~kg}$. Thomson and Freeman (1967) examined the inbreeding effect on milk production. They evaluated all animals born between the years 1930 and 1964 in an Iowa State University herd in the USA. The regression was $-23.0 \pm 11 \mathrm{~kg}$ of milk. Miglior (1992, 1995a, 1995b) intensively studied the influence of inbreeding on production traits in cattle. In a group of 150000 Jersey cows the authors calculated a regression coefficient for milk production on the level of $-9.84 \mathrm{~kg}$ of milk (Miglior, 1992). With $F_{x}$ 
coefficients over $12.5 \%$ the inbreeding depression was even more noticeable. In the same year, Miglior (1995b) evaluated the level of inbreeding in Holstein cattle. The author based his calculations on kinship and milk yield in cows in the $1^{\text {st }}$ lactation in a Canadian population involving more than 92000 Holstein cows. The calculated depression was $-25 \mathrm{~kg}$ of milk for each $1 \%$ rise in inbreeding coefficient. The author also reported a positive correlation for inbreeding and fat and protein content. For $F_{x}=5.0 \%$ the increase in fat was $0.025 \%$ and for $F_{x}=12.5 \%$ the fat increased by $0.0625 \%$. Similar conclusions were reached by Casanova et al. (1992) who studied the influence of inbreeding in the Braunvieh breed in Switzerland. The authors found an increase in milk protein of $0.001 \% / 1 \% \mathrm{~F}_{\mathrm{x}}$. Krogmeier et al. (1997) calculated a reduced milk yield for each \% increase in $\mathrm{F}_{\mathrm{x}}$ in the $1^{\text {st }}, 2^{\text {nd }}$ and $3^{\text {rd }}$ lactations between $-10,14$ and $-11,01 \mathrm{~kg}$ of milk. Smith et al. (1998) conducted a large study on inbreeding. They found the average inbreeding depression for $1 \%$ rise in the value of inbreeding coefficient was $-26.65 \mathrm{~kg}$ of milk in the $1^{\text {st }}$ lactation. Inbreeding depression per $\mathrm{kg}$ of fat and protein was -0.9 andf $-0.8 \mathrm{~kg}$. The lifelong production showed a depression of $-177.17 \mathrm{~kg}$ of milk, $-6.0 \mathrm{~kg}$ of fat and $-5.5 \mathrm{~kg}$ of protein. Hermas et al. (1987) observed the inbreeding depression in two herds in the USA and calculated an increase in fat of $+0.002 \%$ when the $F_{x}$ coefficient increased by $1 \%$. The effect of inbreeding on milk production in Irish Holstein-Friesian dairy cows was studied by Parland et al. (2007). In $12.5 \%$ of inbred cows, milk production declined by $61.8 \mathrm{~kg}$. The $12.5 \%$ inbred animals also had a $2 \%$ greater probability of dystocia and a greater incidence of stillbirth. A similar inbreeding depression was found in Holstein cows in the Czech Republic (Bezdiček et al., 2008).

Thompson et al., (2000b) calculated the level of inbreeding depression in Holstein cattle. For example, for $F_{x}=0.5 ; 0.10$ and 0.264 , the depression in $\mathrm{kg}$ of fat was $5.47 ;-13.83$ and -23.33 . In these groups, the inbreeding depression in $\mathrm{kg}$ of protein was -3.62 ; -10.81 and -19.93 . These authors came to the same conclusion in the case of Jersey cattle (Thompson et al., 2000a). The reduction in $\mathrm{kg}$ of fat in these groups was $-5.11 ;-8.7$ a -16.46 . Inbreeding depression in protein was $-0.32 ;-8.71$ and $-12.17 \mathrm{~kg}$. The negative regression coefficient of inbreeding for $\mathrm{kg}$ of fat and protein in Persey cattle in Canada was calculated by Miglior et al. (1992). 154689 Jersey cows born after the year 1955 were analysed (out of which 53592 were in the first lactation). When $F_{x}$ increased by $1 \%$ the production of fat decreased by $-0.55 \mathrm{~kg}$ (animal model) and $-0.62 \mathrm{~kg}$ (fixed model). When $\mathrm{F}_{\mathrm{x}}$ was over $12.5 \%$ the inbreeding depression was even more marked. Miglior studied a similar problem in Holstein cattle (inbreeding effects on $\mathrm{kg}$ of fat and protein). The highest proportion of cows was in the group with an $\mathrm{F}_{\mathrm{x}}$ lower than $6.25 \%$ (82.24\% of cows). The decrease in fat was $-0.965 / 1 \%$ $\mathrm{F}_{\mathrm{x}}$ and for $\mathrm{kg}$ of protein $-0.875 / 1 \% \mathrm{~F}_{\mathrm{x}}$. This evaluation was made using a fixed model - Miglior et al.
(1995). Kasarda and Kadlečík (2007) evaluated the influence of inbreeding in Pinzgau cattle, bred in Slovakia. 1611 pedigreed breeding cows born between the years 1998-2003 were included in the research. The ratio of inbred cows in the purebred population was $5.7 \%$. The average $\mathrm{F}_{\mathrm{x}}=4.225 \%$. The inbreeding depression was $-8.95 \mathrm{~kg}$ in estimated breeding value (EBV) of milk production, $-0.37 \mathrm{~kg}$ in EBV of fat and $-0.36 \mathrm{~kg}$ in EBV of protein. An inbreeding depression has also been found in other breeds such as buffaloes in Southern Iran (Mirhabibi et at., 2007), and Egyptian buffaloes (Khattab et al., 2007).

In sum, research worldwide shows that inbreeding is closely related to the health of the animals and the economics of cattle breeding. However, selection cannot be based only on phenotype manifestation of traits which are detected by checking milk yield. The selection is made according to hereditary disposition which is defined by breeding value. In this study we focused on inbreeding effects on fat and protein production (in $\mathrm{kg}$ ) during the $1^{\text {st }}$ lactation of Holstein cows.

\section{MATERIALS AND METHODS}

The aim of this study was to explore the depression effects of level of inbreeding on kg of milkfat and milkprotein presented in the form of breeding values. The database included cows of the Holstein strain $(\mathrm{H}=100 \%)$. For proper comparison, each inbred cow (range of $F_{x}$ coefficient $1.125-12.5 \%$ ) was paired with at least one outbred equal (2689 equals in sum). Inbred cows with their outbred equals were matched on characteristics such as (1) identical sire, (2) first calving interval occurring at the same farm, (3) first calving in the same year and period ( \pm 2 months) and (4) dam reaching the same breeding value ( $\pm 5 \%$ ). Inbred cows and their matched outbred equals were subsequently divided according to the inbreeding coefficients of inbred cows into four groups $\left(\mathrm{F}_{\mathrm{x}}=1.25 \%, \mathrm{~F}_{\mathrm{x}}=2.0-3.125 \%, \mathrm{~F}_{\mathrm{x}}=4.0-12.5 \%\right.$ and $\mathrm{F}_{\mathrm{x}}=$ total, all animals). The level of inbreeding inbreeding coefficient $F_{x}$, was calculated as follows (Wright, 1922):

$$
\mathrm{F}_{\mathrm{x}}=\Sigma(0.5)^{\mathrm{n}+\mathrm{n}^{\prime}+1}\left(1+\mathrm{F}_{\mathrm{a}}\right)
$$

$\Sigma$.... sum over all path through to common ancestor $n$.... the number of generations from the sire to the common ancestor

$n '$... the number of generations from the dam to the common ancestor

$F_{a}$... the inbreeding coefficient of the common ancestor.

Data were analysed using PROC GLM of SAS. The effects of inbreeding and other factors were estimated from the model as follows:

$$
Y_{i j k l m n o}=\mu+F_{i}+A C_{j}+Y C_{k}+C L_{l}+C I_{m}+B V S_{n}+B V M_{o}+
$$

$\mathrm{Y}_{\mathrm{ijklmno}}$... corrected breeding value for protein (or fat) $\mathrm{kg}$ 
$\mu$.............mean value

$\mathrm{F}_{\mathrm{i}} \ldots \ldots \ldots . . . \mathrm{F}_{\mathrm{x}}$ level of coefficient $/$ in $\% /\left(\mathrm{F}_{\mathrm{x}}=1.25, \mathrm{~F}_{\mathrm{x}}=\right.$ $\left.2.0-3.125, \mathrm{~F}_{\mathrm{x}}=4.0-12.5\right)$

$\mathrm{AC}_{\mathrm{j}} \ldots . . . . .$. age at first calving /in months/ $(\leq 25.0$; 25.1-28.0; 28.1 $\geq$ )

$\mathrm{YC}_{\mathrm{k}}$........year of first calving ( $\leq 1995$; 1996-1998; 1999-2000; 2001 $\geq$ )

$\mathrm{CL}_{1} \ldots . . . .$. sum of lactations $(\leq 1.5 ; 1.6-2.5 ; 2.6-3.5$; 3.6 $\geq)$

$\mathrm{CI}_{\mathrm{m}}$......... first calving interval /days/ $(\leq 400 ; 401 \geq$; only $1^{\text {st }}$ lactation)

BVS $_{n}$..... relative breeding value of the sire for milk production in $\mathrm{kg}(\leq 94 ; 95-108 ; 109 \geq)$

$\mathrm{BVM}_{\mathrm{o}}$.... relative breeding value of the dam for milk production in $\mathrm{kg}(\leq 94 ; 95-108 ; 109 \geq)$

$\mathrm{e}_{\mathrm{ijk} k \mathrm{mno}}$.... residual error.

Calculations were processed for inbred cows and outbred equals separately. A comparison of average values for outbred and inbred groups for the same $\mathrm{F}_{\mathrm{x}}$ level was then made (by post-hoc analysis-Tukey HSD test).

In this study, the data included cows calved in the years 1990-2006 at farms in the Czech Republic. The processing of breeding value data and monitoring of milk traits were completed around August 2008. The data were analysed for 273227 Holstein cows.

\section{RESULTS AND DISCUSSION}

Differences in the breeding values of fat and protein for the two groups of inbred and outbred cows are shown in Tab. I and Tab. II.

Tab. I shows the breeding values of fat and Tab. II shows the breeding values of protein. Both evaluated milk components show an evident decline in breeding value when the level of inbreeding was higher. On the other hand, the coevals of these cows showed equal values or even slight increase. Compared to their coevals, inbred cows had lower breeding values. Within the groups $\left(\mathrm{F}_{\mathrm{x}}=1.25 \%, \mathrm{~F}_{\mathrm{x}}=\right.$ $\left.2.0-3.125 \%, \mathrm{~F}_{\mathrm{x}}=4.0-12.5 \%\right)$ the average breeding values for inbred cows (and their coevals) in kg of protein were 4.78 (5.33); 4.35 (5.23); 3.20 (7.19) kg. A similar tendency was apparent in the breeding values of inbred cows (coevals) in $\mathrm{kg}$ of fat 4.18 (4.89); 4.37 (4.59) a 3.42 (7.11) - Tab. I and Tab. II. These results demonstrate clearly not only the decrease in $\mathrm{kg}$ of fat and protein linked to increasing levels of inbreeding but also lower values reached by inbred cows compared to their outbred cohorts.

Tab. I and Tab. II also reveal that raising the level of parents (their RBV) causes a very significant increase in production both in inbred and outbred cows. E.g. when the RBV values of the sire were the lowest, the inbred (also outbred) cows had a lower production of both protein $-3.41(-0.50)$ and fat content -2.06 (0.87). On the other hand when the RBVs of the sire were the highest, the inbred (also outbred) cows had a higher production of protein 11.64 (12.19) and fat 9.65 (9.49) - Tab. I and Tab. II. We can see the same tendency in the breeding values of the dam.

Tab. III show the tendency towards lower breeding values of milk components for the inbred cows. There are differences in corrected breeding values for protein (or fat) in $\mathrm{kg}$ between the inbred and outbred cows. The fixed effects $\left(\mathrm{Y}_{\mathrm{ijkmno}}\right)$ were taken into account here. The decrease in production of protein (fat) in the inbred animals was $\left(\mathrm{F}_{\mathrm{x}}=1.25, \mathrm{~F}_{\mathrm{x}}=\right.$ 2.0-3.125, $\left.\mathrm{F}_{\mathrm{x}}=4.0-12.5\right)$ as follows: $-0.58(-1.48)$; -0.48 (0.17); -3.21 (-8.26) kg. Within the corrected breeding values $\left(\mathrm{Y}_{\mathrm{ijklmno}}\right)$ for $\mathrm{kg}$ of fat and protein the higher variability of values in inbred animals is apparent. This variability can be found in all inbred groups and also in an „all animals" group. These results follow the same trend as the results of other authors. The literature shows that inbreeding causes a decline in milk production (in $\mathrm{kg}$ ) and also a slight increase in percentage of fat and protein in inbred cows. When expressing production in $\mathrm{kg}$ of fat and $\mathrm{kg}$ of protein most authors agree on the negative correlation. Miglior. et al. (1992) came to the same conclusions for Jersey cows. They demonstrated that the production of fat decreased by -0.55 and of protein by $-0.62 \mathrm{~kg} / 1 \% \mathrm{~F}_{\mathrm{x}}$. The same authors (Miglior, 1995a) found a reduction in $\mathrm{kg}$ of fat of -0.965 and in $\mathrm{kg}$ of protein $-0.875 / 1 \% \mathrm{~F}_{\mathrm{x}}$ in Holstein cattle. Smith et al. (1998) reported a similar level of depression. The inbreeding depression in $\mathrm{kg}$ of protein and fat was -0.9 and $-0.8 \mathrm{~kg}$. The lifelong production showed a depression of $-177.17 \mathrm{~kg}$ of milk, $-6.0 \mathrm{~kg}$ of fat and $-5.5 \mathrm{~kg}$ of protein. Thompson et al. (2000b) calculated the level of inbreeding depression in Holstein cows for different levels of $F_{x}$ coefficient. For example, when the $F_{x}=0.5 ; 0.10$ and 0.264 the depression of $\mathrm{kg}$ of fat was -5.47 ; -13.83 and -23.33 ; inbreeding depression for $\mathrm{kg}$ of protein within these groups was $-3.62 ;-10.81$ and -19.93 . Kasarda and Kadlečík (2007) came to similar conclusions. These authors described the inbreeding depression in estimated breeding value of fat was $-0.37 \mathrm{~kg}$ and in estimated breeding value of protein $-0.36 \mathrm{~kg}$.

\section{CONCLUSIONS}

This study shows a change in breeding values of $\mathrm{kg}$ of fat and $\mathrm{kg}$ of protein in inbred cows compared to their noninbred coevals. When the coefficient $F_{x}$ was high (4.0-12.5), the decrease was statistically significant or highly significant.

It was also evident that increasing the level of parents (their RBV) caused a very significant increase in production in both inbred and outbred cows but greater increase in fat or protein production was found in the noninbred cows. 
I: Post-hoc analysis of fat content (in $\mathrm{kg}$ ) within each of model effects

\begin{tabular}{|c|c|c|c|c|c|c|c|c|c|}
\hline \multirow[t]{2}{*}{ Effects } & & $F x=1.25 \%$ & $\begin{array}{c}\text { Outbred } \\
\text { equals }\end{array}$ & $\begin{array}{c}F x= \\
2.0-3.125 \%\end{array}$ & $\begin{array}{c}\text { Outbred } \\
\text { equals }\end{array}$ & $\begin{array}{c}F x= \\
4.0-6.25 \%\end{array}$ & $\begin{array}{c}\text { Outbred } \\
\text { equals }\end{array}$ & $\begin{array}{l}\text { All inbred } \\
\text { animals }\end{array}$ & $\begin{array}{c}\text { All Outbred } \\
\text { equals }\end{array}$ \\
\hline & & LSM & LSM & LSM & LSM & LSM & LSM & LSM & LSM \\
\hline \multirow{4}{*}{$\mathbf{F x}$} & 1 & & & & & & & 4.18 & 4.89 \\
\hline & 2 & & & & & & & 4.37 & 4.59 \\
\hline & 3 & & & & & & & 3.42 & 7.11 \\
\hline & p & & & & & & & n.s. & $2-3 *$ \\
\hline \multirow{4}{*}{$\begin{array}{l}\text { Age at } \\
\text { first } \\
\text { calving }\end{array}$} & 1 & 4.50 & 5.15 & 2.39 & 4.06 & 7.99 & 6.54 & 3.57 & 5.08 \\
\hline & 2 & 8.23 & 2.41 & 2.71 & 5.54 & 3.98 & 8.42 & 3.96 & 5.99 \\
\hline & 3 & 4.84 & 1.97 & 5.64 & 4.53 & -0.70 & 6.22 & 4.47 & 5.20 \\
\hline & $\mathrm{p}$ & n.s. & n.s. & $\begin{array}{l}1-3 * \\
2-3 *\end{array}$ & n.s. & $1-3 *$ & n.s. & n.s. & n.s. \\
\hline \multirow{5}{*}{$\begin{array}{l}\text { Year of } \\
\text { calving }\end{array}$} & 1 & 8.73 & 8.25 & 6.07 & 6.55 & 6.87 & 7.77 & 6.93 & 7.42 \\
\hline & 2 & 6.91 & 3.37 & 2.62 & 4.40 & 9.34 & 10.60 & 4.34 & 5.44 \\
\hline & 3 & 2.25 & 3.73 & 3.49 & 4.67 & -4.12 & 2.77 & 2.31 & 5.27 \\
\hline & 4 & 5.52 & -2.64 & 2.14 & 3.19 & 2.92 & 7.09 & 2.43 & 3.56 \\
\hline & $\mathrm{p}$ & n.s. & $\begin{array}{l}1-4^{* *} \\
3-4^{*}\end{array}$ & n.s. & n.s. & $\begin{array}{c}1-3 * * \\
2-3 * * \\
2-4 *\end{array}$ & n.s. & $\begin{array}{l}1-3 * * \\
1-4 *\end{array}$ & $1-4 * *$ \\
\hline \multirow{5}{*}{$\begin{array}{l}\text { Sum of } \\
\text { lactations }\end{array}$} & 1 & 4.50 & 9.71 & 5.81 & 5.63 & 2.58 & 6.95 & 4.75 & 7.35 \\
\hline & 2 & 6.73 & -0.44 & -3.16 & 3.94 & 0.96 & 8.25 & 0.79 & 4.36 \\
\hline & 3 & 7.66 & 2.89 & 9.11 & 3.68 & 2.99 & 7.55 & 7.28 & 4.88 \\
\hline & 4 & 2.72 & 0.54 & 2.61 & 5.58 & 3.75 & 5.49 & 2.47 & 5.09 \\
\hline & $\mathrm{p}$ & n.s. & $\begin{array}{l}1-2^{* *} \\
1-3 * * \\
1-4 * *\end{array}$ & $\begin{array}{c}2-3 * \\
3-4^{* *} \\
3-5^{*}\end{array}$ & n.s. & n.s. & n.s. & $3-4 *$ & $1-2^{*}$ \\
\hline \multirow{4}{*}{$\begin{array}{l}\text { Calving } \\
\text { interval }\end{array}$} & 1 & 4.98 & 5.84 & 3.43 & 3.32 & 4.51 & 5.51 & 3.63 & 4.74 \\
\hline & 2 & 2.32 & 5.09 & 3.72 & 6.08 & 3.39 & 8.61 & 3.45 & 6.87 \\
\hline & 3 & 10.26 & -1.41 & 3.60 & 4.71 & 3.37 & 7.06 & 4.93 & 4.66 \\
\hline & p & $2-3 *$ & $1-3 *$ & n.s. & $1-2 *$ & n.s. & n.s. & n.s. & $1-2 *$ \\
\hline \multirow{4}{*}{ BVS } & 1 & -0.44 & -3.21 & -1.85 & 0.85 & 4.50 & 2.82 & -2.06 & 0.87 \\
\hline & 2 & 5.56 & 6.17 & 3.66 & 4.71 & 6.36 & 6.24 & 4.41 & 5.91 \\
\hline & 3 & 12.43 & 6.56 & 8.93 & 8.56 & 9.42 & 12.11 & 9.65 & 9.49 \\
\hline & $\mathrm{p}$ & $\begin{array}{l}1-2^{*} \\
1-3^{* *}\end{array}$ & $\begin{array}{l}1-2^{* *} \\
1-3^{* *}\end{array}$ & $\begin{array}{l}1-2^{* *} \\
1-3^{* *} \\
2-3 * *\end{array}$ & $\begin{array}{l}1-2 * * \\
1-3 * * \\
2-3 * *\end{array}$ & $\begin{array}{l}1-2 * * \\
1-3 * *\end{array}$ & $1-3 * *$ & $\begin{array}{l}1-2 * * \\
1-3 * * \\
2-3 * *\end{array}$ & $\begin{array}{l}1-2^{* *} \\
1-3^{* *} \\
2-3^{* *}\end{array}$ \\
\hline \multirow{4}{*}{ BVM } & 1 & 1.38 & 0.59 & -1.92 & 0.91 & 2.48 & 5.87 & -0.40 & 1.84 \\
\hline & 2 & 7.20 & 4.53 & 4.22 & 4.21 & 2.33 & 6.56 & 4.54 & 5.52 \\
\hline & 3 & 8.99 & 5.59 & 8.45 & 9.01 & 4.13 & 8.74 & 7.86 & 8.91 \\
\hline & $\mathrm{p}$ & $\begin{array}{l}1-2^{*} \\
1-3^{* *}\end{array}$ & $\begin{array}{l}1-2^{*} \\
1-3^{* *}\end{array}$ & $\begin{array}{l}1-2^{* *} \\
1-3 * * \\
2-3 *\end{array}$ & $\begin{array}{c}1-2^{*} \\
1-3 * * \\
2-3 * *\end{array}$ & n.s. & n.s. & $\begin{array}{c}1-2 * * \\
1-3 * * \\
2-3 *\end{array}$ & $\begin{array}{l}1-2^{* *} \\
1-3 * * \\
2-3 * *\end{array}$ \\
\hline
\end{tabular}

$* \mathrm{p} \leq 0.05 ; * * \mathrm{p} \leq 0.01 ;$ n.s. $=$ non significant

BVS - Relative breeding value of the sire for milk production in kg; BVM - Relative breeding value of the dam for milk production in $\mathrm{kg}$ 
II: Post-hoc analysis of protein content (in $\mathrm{kg}$ ) within each of model effects

\begin{tabular}{|c|c|c|c|c|c|c|c|c|c|}
\hline \multirow{2}{*}{\multicolumn{2}{|c|}{ Effects }} & $F x=1.25 \%$ & $\begin{array}{c}\text { Outbred } \\
\text { equals }\end{array}$ & $\begin{array}{c}F x= \\
2.0-3.125 \%\end{array}$ & $\begin{array}{c}\text { Outbred } \\
\text { equals }\end{array}$ & $\begin{array}{c}F x= \\
4.0-6.25 \%\end{array}$ & $\begin{array}{c}\text { Outbred } \\
\text { equals }\end{array}$ & $\begin{array}{l}\text { All inbred } \\
\text { animals }\end{array}$ & $\begin{array}{c}\text { All outbred } \\
\text { equals }\end{array}$ \\
\hline & & LSM & LSM & LSM & LSM & LSM & LSM & LSM & LSM \\
\hline \multirow{4}{*}{$\mathbf{F x}$} & 1 & & & & & & & 4.78 & 5.33 \\
\hline & 2 & & & & & & & 4.35 & 5.23 \\
\hline & 3 & & & & & & & 3.20 & 7.19 \\
\hline & $\mathrm{p}$ & & & & & & & n.s. & $2-3 *$ \\
\hline \multirow{4}{*}{$\begin{array}{l}\text { Age at first } \\
\text { calving }\end{array}$} & 1 & 10.38 & 7.41 & 2.73 & 5.29 & 8.84 & 6.88 & 4.82 & 6.30 \\
\hline & 2 & 11.10 & 4.82 & 2.54 & 4.52 & -0.55 & 9.31 & 3.19 & 5.73 \\
\hline & 3 & 11.80 & 6.55 & 4.13 & 5.63 & -0.72 & 6.17 & 4.31 & 5.72 \\
\hline & $\mathrm{p}$ & n.s. & n.s. & n.s. & n.s. & $\begin{array}{l}1-2^{* *} \\
1-3 *\end{array}$ & n.s. & n.s. & n.s. \\
\hline \multirow{5}{*}{$\begin{array}{l}\text { Year of } \\
\text { calving }\end{array}$} & 1 & 15.39 & 9.68 & 4.61 & 6.27 & 5.00 & 5.09 & 6.36 & 6.63 \\
\hline & 2 & 12.95 & 5.30 & 4.01 & 5.10 & 9.42 & 9.08 & 5.63 & 6.02 \\
\hline & 3 & 6.35 & 5.67 & 2.14 & 4.20 & -2.61 & 6.43 & 1.61 & 5.02 \\
\hline & 4 & 9.68 & 4.39 & 1.78 & 5.03 & 1.58 & 9.21 & 2.83 & 5.99 \\
\hline & $\mathrm{p}$ & $\begin{array}{l}1-3 * * \\
2-3 *\end{array}$ & n.s. & n.s. & n.s. & $\begin{array}{l}2-3 * \\
2-4^{*}\end{array}$ & n.s. & $\begin{array}{l}1-3 * * \\
2-3 * * \\
2-4 *\end{array}$ & n.s. \\
\hline \multirow{5}{*}{$\begin{array}{l}\text { Sum of } \\
\text { lactations }\end{array}$} & 1 & 5.24 & 9.06 & 6.78 & 6.35 & 1.68 & 3.96 & 5.16 & 6.91 \\
\hline & 2 & 25.89 & 3.74 & -1.67 & 5.46 & -0.60 & 10.36 & 2.16 & 6.05 \\
\hline & 3 & 10.75 & 4.56 & 6.11 & 4.11 & 4.16 & 8.53 & 6.49 & 4.75 \\
\hline & 4 & 5.75 & 7.69 & 2.30 & 4.67 & 3.92 & 6.96 & 2.99 & 5.97 \\
\hline & $\mathrm{p}$ & $\begin{array}{l}1-2 * \\
1-3 *\end{array}$ & $\begin{array}{l}1-2 * \\
1-3 *\end{array}$ & $\begin{array}{l}1-4 * 1-5 * \\
3-4 * 3-5 *\end{array}$ & n.s. & n.s. & n.s. & $3-4 * *$ & $1-3 *$ \\
\hline \multirow{4}{*}{$\begin{array}{l}\text { Calving } \\
\text { interval }\end{array}$} & 1 & 10.50 & 7.99 & 3.65 & 4.81 & 1.76 & 3.33 & 4.07 & 5.30 \\
\hline & 2 & 7.82 & 6.12 & 3.74 & 5.78 & 2.57 & 7.64 & 3.57 & 6.17 \\
\hline & 3 & 14.96 & 4.66 & 2.02 & 4.86 & 5.72 & 11.39 & 4.68 & 6.28 \\
\hline & $\mathrm{p}$ & $2-3 *$ & n.s. & n.s. & n.s. & n.s. & $1-3 *$ & n.s. & n.s. \\
\hline \multirow{4}{*}{ BVS } & 1 & 2.91 & -1.51 & -4.32 & $-1,58$ & -5.35 & 2.21 & -3.41 & -0.50 \\
\hline & 2 & 8.50 & 4.38 & 2.67 & 5.44 & 7.27 & 8.12 & 4.10 & 6.06 \\
\hline & 3 & 21.87 & 15.91 & 11.05 & 11.58 & 8.13 & 12.03 & 11.64 & 12.19 \\
\hline & $\mathrm{p}$ & $\begin{array}{l}1-2 * \\
1-3 * * \\
2-3 * *\end{array}$ & $\begin{array}{l}1-2 * * \\
1-3 * * \\
2-3 * *\end{array}$ & $\begin{array}{l}1-2 * * \\
1-3 * * \\
2-3 * *\end{array}$ & $\begin{array}{l}1-2^{* *} \\
1-3^{* *} \\
2-3 * *\end{array}$ & $\begin{array}{l}1-2^{* *} \\
1-3^{* *}\end{array}$ & $\begin{array}{l}1-2 * \\
1-3 * *\end{array}$ & $\begin{array}{l}1-2^{* *} \\
1-3^{* *} \\
2-3^{* *}\end{array}$ & $\begin{array}{l}1-2^{* *} \\
1-3^{* *} \\
2-3 * *\end{array}$ \\
\hline \multirow{4}{*}{ BVM } & 1 & 6.24 & 1.92 & -1.32 & 1.32 & 2.04 & 4.63 & 0.25 & 2.02 \\
\hline & 2 & 12.72 & 6.30 & 3.58 & 4.50 & 1.58 & 6.87 & 4.29 & 5.32 \\
\hline & 3 & 14.31 & 10.57 & 7.14 & 9.63 & 3.94 & 10.86 & 7.78 & 10.41 \\
\hline & $\mathrm{p}$ & $\begin{array}{l}1-2 * * \\
1-3 * *\end{array}$ & $\begin{array}{l}1-2 * * \\
1-3 * * \\
2-3 *\end{array}$ & $\begin{array}{l}1-2 * * \\
1-3 * * \\
2-3 * *\end{array}$ & $\begin{array}{l}1-2^{* *} \\
1-3 * * \\
2-3 * *\end{array}$ & n.s. & $1-3 *$ & $\begin{array}{l}1-2^{* *} \\
1-3^{* *} \\
2-3^{* *}\end{array}$ & $\begin{array}{l}1-2^{* *} \\
1-3 * * \\
2-3 * *\end{array}$ \\
\hline
\end{tabular}

$* \mathrm{p} \leq 0.05 ; * * \mathrm{p} \leq 0.01 ;$ n.s. $=$ non significant

BVS - Relative breeding value of the sire for milk production in $\mathrm{kg}$; BVM - Relative breeding value of the dam for milk production in $\mathrm{kg}$ 
Tab. III: Comparison of predicted breeding values inbred and outbred cows (Fat and Protein in kg)

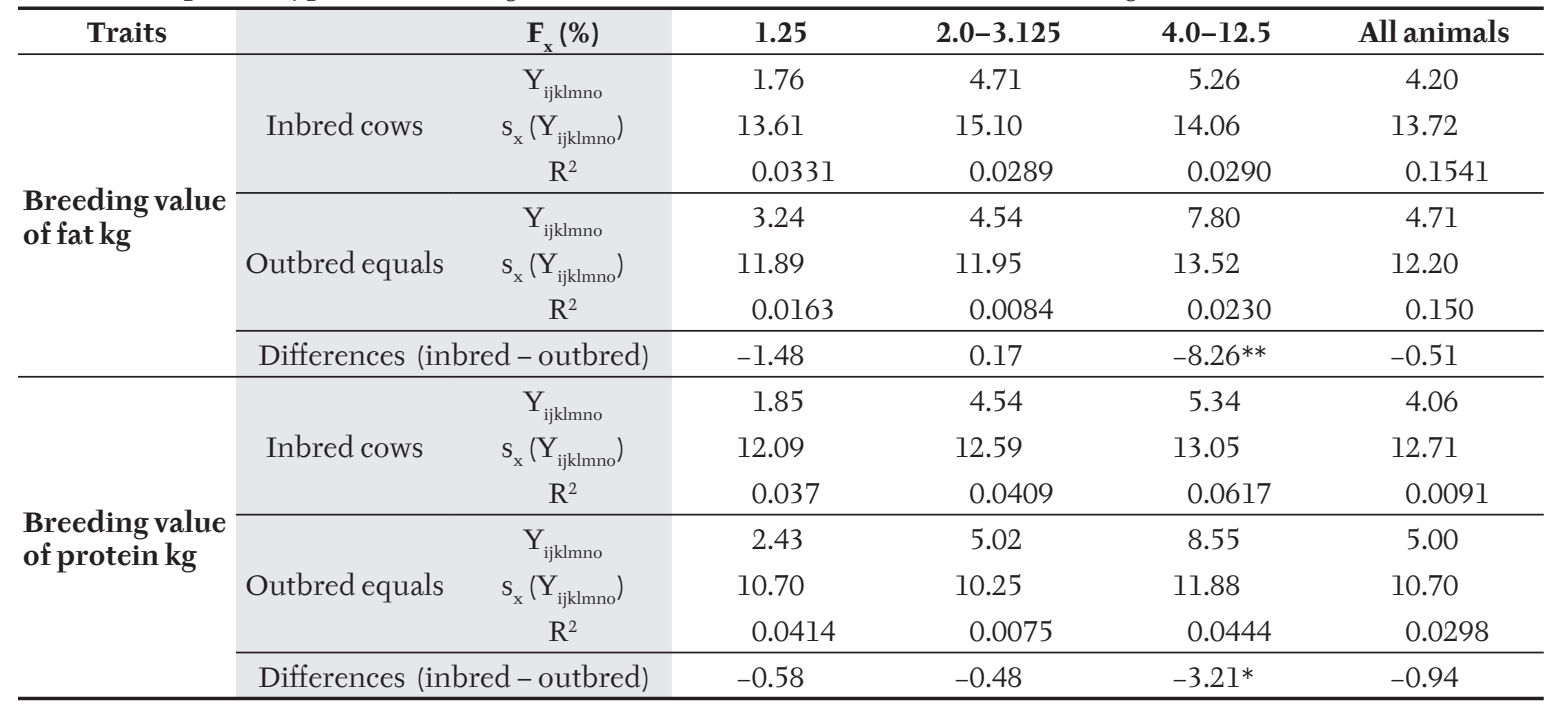

${ }^{*} \mathrm{p} \leq 0.05 ; * * \mathrm{p} \leq 0.01 ;$ n.s. $=$ non significant; $\mathrm{Y}_{\mathrm{ijklmno}}=$ corrected breeding values for the protein (fat) in $\mathrm{kg}$

\section{SOUHRN}

Vyhodnocení produkce mléčného tuku a bílkovin inbredních a outbredních holštýnských krav

Cílem práce bylo zjištění vlivu stupně inbreedingu na produkci tuku a bílkovin, prezentované ve formě plemenných hodnot. Soubor dat zahrnoval krávy narozené v letech 1990-2006 na farmách v České republice. Inbrední krávy byly seřazeny do skupin podle velikosti koeficientu $\mathrm{F}_{\mathrm{x}}\left(\mathrm{F}_{\mathrm{x}}=1,25 \%\right.$, $\mathrm{F}_{\mathrm{x}}=2,0-3,125 \%, \mathrm{~F}_{\mathrm{x}}=4,0-12,5 \%$ a $\mathrm{F}_{\mathrm{x}}=$ celkem). Plemenné hodnoty inbredních krav byly srovnávány s hodnotami jejich neinbredních vrstevnic $(n=2689)$ - polosestrami se shodným otcem, které měly matku se shodnou plemennou hodnotou ( $\pm 5 \%$ ), a které ukončily svoji první lataci na stejné farmě a ve stejném čase ( \pm 2 měsíce). Pro výpočet byl použit program PROC GLM of SAS"s pěti fixními efekty (věk při prvním otelení, rok otelení, počet laktací, mezidobí a relativní plemenná hodnota otce a matky).

Ve sledovaných skupinách koeficientu $\mathrm{F}_{\mathrm{x}}\left(\mathrm{F}_{\mathrm{x}}=1,25 \%, \mathrm{~F}_{\mathrm{x}}=2,0-3,125 \%, \mathrm{~F}_{\mathrm{x}}=4,0-12,5 \%\right.$ and $\mathrm{F}_{\mathrm{x}}=$ total $)$ jsme zjistili pokles plemenných hodnot kg tuku inbredních krav o -1,48; 0,17; -8,26 a -0,51 kg. Také v případě kg bílkovin byla zjištěna nižší produkce inbredních krav: -0,58; -0,48; -3,21 a -0,94kg. Tyto diference byly signifikantní $(\mathrm{p} \leq 0,01)$ ve skupinách $\mathrm{s}$ vyšším koeficientem inbreedingu $\left(\mathrm{F}_{\mathrm{x}}=\right.$ 4,0-12,5\%). Inbrední zvířata také vykazovala vyšší variabilitu v rámci s $\mathrm{x}_{\mathrm{x}}\left(\mathrm{Y}_{\mathrm{ijklmn}}\right)$.

Bylo také zřejmé, že nárůst kvality rodičů (jejich plemenné hodnoty) podmiňoval vysoce průkazné zvýšení produkce jejich inbredních, event. neinbredních dcer. Vyšší nárůst produkce tuku, event. bílkovin byl ale ve skupině neinbredních krav.

inbrední deprese, kg bílkovin, kg tuku, holštýnské krávy

This study was supported by research projects MSM 2678846201 and 2B08037.

\section{REFERENCES}

ALLAIRE, F. R. AND HENDERSON, C. R., 1965: Inbreeding Within an Artificially Bred Dairy Cattle Population. J. Dairy Sci., 48, 1366-1371.

BEZDÍČEK, J., ŠUBRT, J., FILIPČÍK, R., BJELKA, M., DUFEK, A., 2007: The effects of inbreeding on service period and pregnancy length in Holsteins and Czech Fleckviehs after the first calving, Arch. Tierz., 50, 455-463.
BEZDÍČEK, J., ŠUBRT, J., FILIPČÍK, R., 2008: The effect of inbreeding on milk traits in Holstein cattle in the Czech Republic, Arch. Tierz., 51, 415-425.

CASANOVA, L., HAGGER, C., KUENZI, N., 1992: Inbreeding in Swiss Braunvieh and Its Influence on Breeding Values Predicted from a Repeatability Animal Model, J. Dairy Sci., 75, 1119-1126.

CASSELL, B. G., ADAMEC, V., PEARSON, R. E., 2003: Effect of Incomplete Pedigrees on Estimates 
of Inbreeding and Inbreeding Depression for Days to First Service and Summit Milk Yield in Holsteins and Jerseys, J. Dairy Sci., 86, 2967-2976.

CASSELL, B. G., SMITH, L. A., PEARSON, R. E., 1998: The Effects of Inbreeding on the Lifetime Performance of Dairy Cattle, J. Dairy Sci., 81, 2729-2737.

GAALAAS, R. F., HARVEY, W. R., PLOWMAN, R.D., 1962: Effect of Inbreeding on Production in Different Lactations, J. Dairy Sci., 45, 671.

HERMAS, S. A., YOUNG, C. W., RUST, J. W., 1987: Effects of Mild Inbreeding on Productive and Reproductive Performance of Guernsey Cattle, J. Dairy Sci., 70, 712-714.

KASARDA, R. AND KADLEČÍK, O., 2007: An economic impact of inbreeding in the purebred population of Pinzgau cattle in Slovakia on milk production traits, Czech J. Anim. Sci., 52, 7-11.

KHATTAB, A. S., KAWTHAR, A. M., 2007: Inbreeding and it is effects on some productive and reproductive traits in a herd of Egyptian buffaloes, Ital. J. Anim. Sci., 6, 375-378.

KROGMEIER, D., AUMANN, J., AVENDUNK, G., 1997: Inbreeding in German Gelbvieh and German Braunvieh. Züchtungskunde, 69, 233-243.

MIGLIOR, F., 1992: Analysis of Levels of Inbreeding and Inbreeding Depression in Jersey Cattle, J. Dairy Sci., 75, 1112-1118.

MIGLIOR, F., 1995A: Inbreeding of Canadian Holstein Cattle, J. Dairy Sci., 78, 1163-1167.

MIGLIOR, F., 1995B: Production Traits of Holstein Cattle-Estimation of Nonadditive Genetic Variance Components and Inbreeding Depression, J. Dairy Sci., 78, 1174-1180.

MIRHABIBI, S., MANAFIAZAR, G. H., QARAVISI, S. H., MAHMOODI, B., 2007: Inbreeding and its effect on some productive traits in buffaloes of South Iran, Ital. J. Anim. Sci., 6, 372-374.

PARLAND, MC. S., KEARNEY, J. F., RATH, M., BERRY, D. P., 2007: Inbreeding Effects on Milk Production, Calving Performance, Fertility, and Conformation in Irish Holstein-Friesians, J. Dairy Sci., 90, 4411-4419.

SAS Copyright $1999-2001$ by SAS Institute Inc., Cary, NC, USA, 8.2.

SHARMA, R., PANDEY, A. K., SINGH, Y., PRAKASH, B., 2006: Evaluation of Genetic Variability in Ponwar Cattle by Microsatelite Markers, J. Appl. Anim. Res., 30, 63-67.

SMITH, L. A., CASSELL, B. G., PEARSON, R. E., 1998: The Effects of Inbreeding on the Lifetime Performance of Dairy Cattle, J. Dairy Sci., 81, 2729-2737.

SODHI, M., MUKESH, M., PRAKASH, B., MISHRA, B. P., SOBTI, R. C., 2007: Microsatellite Marker Based Characterization of Genetic Diversity in Kankrej Cattle, J. Appl. Anim. Res., 31, 153-158.

SUTHERLAND, T. M., LUSH, J. L., 1962: Effects of Inbreeding on Size and Type in Holstein-Friesan Cattle, J. Dairy Sci., 45, 390-395.

THOMSON, G. M., FREEMAN, A. E., 1967: Effects of Inbreeding and Selection in a Closed HolsteinFriesian Herd, J. Dairy Sci., 50, 1824-1827.

THOMPSON, J. R., EVERETT, R. W., WOLF, C. W., 2000a: Effects of Inbreeding on Production and Survival in Jerseys, J. Dairy Sci., 83, 2131-2137.

THOMPSON, J. R., EVERETT, R. W., HAMMERSCHMIDT, N. L., 2000B: Fffects of Inbreeding on Production and Survival in Holsteins, J. Dairy Sci., 83, 1856-1864.

WRIGHT, S., 1922: Coefficients of inbreeding and relationship. American Naturalist, 56, 330-338.

Ing. Jiří Bezdíček, Ph.D., Mgr. Jan Říha, Agrovýzkum Rapotín, s. r. o., Výzkumníků 267, 78813 Vikýřovice, prof. Ing. Jan Šubrt, CSc., Ing. Radek Filipčík, Ph.D., Ústav chovu a šlechtění zvířat, Mendelova zemědělská a lesnická univerzita v Brně, Zemědělská 1665/1, 61300 Brno, Česká republika 
